\title{
CARVAlHO, Bernardo. Nove noites. São Paulo: Companhia das Letras, 2002.
}

Fernando Baião Viotti Universidade Federal de Minas Gerais

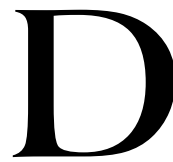

ar conta sinteticamente de uma obra como Nove noites, romance do carioca Bernardo Carvalho, não é tarefa fácil. As dificuldades se impõem a partir de características específicas do livro logo observáveis numa primeira leitura: o relato híbrido que se desenrola entre o espaço da pesquisa documental e o da ficção; o entrelaçamento de duas vozes narrativas de natureza discutível; o tratamento crítico do modelo tradicional de representação literária, questão intrinsecamente ligada às duas anteriores; o olhar áspero, por vezes de comovente dramaticidade, para a morte e para os mortos, que percebemos em variados graus e está apresentado em múltiplos aspectos. Sinais, entre outros, da força surpreendente do livro e do estímulo indiscutível que representa para o leitor interessado.

Diante, portanto, do desafio, parece inevitável privilegiar um dos aspectos de interesse, se o que queremos é uma análise de relativa profundidade capaz de demonstrar a suposta "força" da obra. A escolha nesse caso, que não deixa de ter uma pitada de arbitrariedade, recai sobre a temática da morte, partindo de uma frase, entretanto, com aparente potencial para propor uma reflexão que ao menos toque de leve nos outros temas destacados.

Antes de irmos diretamente à frase cabe lembrar o entrecho do romance. Construído sem malabarismos estilísticos, em linguagem escorreita, econômica mesmo, Nove noites é a narrativa das peripécias de um jornalista em busca de esclarecimentos sobre o suicídio de um antropólogo americano, Buell Quain, nos confins da Amazônia. Ocorrido sem motivos aparentes no longínquo ano de 1938, o suicídio impressiona o narrador principalmente pelos requintes de violência e pela 
intempestividade do ato praticado. No percurso, o narrador irá se deparar com as impossibilidades de conciliação entre as diferentes verdades que lhe oferecem, ao mesmo tempo em que tem de se confrontar com o próprio passado problemático, que teima em vir à tona articulado às terríveis experiências do antropólogo.

Uma dessas verdades, real ou imaginária, é oferecida pelo engenheiro Manoel Pernas, um dos narradores da obra e que teria privado da companhia de Quain por exatamente nove noites, no curto período vivido, no Brasil, pelo antropólogo antes de se matar. Durante suas reflexões iniciais sobre os motivos que teriam levado Quain ao suicídio é que Manoel Pernas dirá: "É preciso não deixar os mortos tomarem conta dos que ficaram".

Mais ou menos solta entre as explicações de Portas sobre as atitudes tomadas após a morte de Quain, a frase acaba sendo uma revelação e uma advertência para o narrador que, sessenta e dois anos depois, empreende sua busca em direção aos motivos do morto. Tomado pela obsessão de compreender o antropólogo, o narrador vai cada vez mais se tornando este vivo que ficou tomado por um morto, enredado num mistério onde atingir a verdade dos fatos é uma aporia.
O narrador parece estar buscando a consciência do morto no momento imediatamente anterior à sua morte, o que o leva a um dilema de impossível solução, pois ao mesmo tempo em que falta ao morto a voz para revelar-se, este também - como a folha em branco que se depara ante o escritor - é o espaço em que tudo pode se projetar.

O risco que corremos, portanto, nós que ficamos, é deixar que os mortos tomem conta de nós a partir principalmente do que não são, do que não disseram, e até mesmo do que não viveram, espaço infinito para a projeção dos que sobre eles se debruçam. É o que leva o narrador a uma busca sem termo, pois os índices e as possibilidades com que se depara em sua pesquisa começam por se mostrar terrível e infinitamente múltiplos, levando à construção daquilo que o próprio Bernardo Carvalho teria chamado em entrevista de "discurso paranóico". Deixar-se tomar pelo morto, risco de qualquer modo inevitável na situação que o livro coloca, é se condenar à incerteza. Não existe na narrativa (existirá fora dela?) a voz de um outro capaz de impor limites claros às elucubrações do narrador, e as poucas tentativas de estabelecer uma verdade peremptória e determinante para os fatos são logo negadas por um discurso posterior.

Desse modo, os indícios, sempre precários, aparecem em curioso 
movimento inverso ao da exegese histórica. Se nesta o passado é o que ilumina e direciona os acontecimentos futuros, na narrativa de Bernardo Carvalho a direção é a mesma, mas o sentido, contrário. É o futuro que ilumina, ou até mesmo transmuta e recria o passado, situação dada a partir inclusive da organização não cronológica da narrativa.

Decerto não é à toa que o narrador esconde do leitor a ocasião em que ouvira o nome de Buell Quain pela primeira vez: "Li várias vezes o mesmo parágrafo e repeti o nome em voz alta para me certificar de que não estava sonhando, até entender - ou confirmar, já não sei - que o tinha ouvido antes".

Assim, quando conhecemos, já no terço final do livro, a situação em que o narrador ouvira, ou pensara ter ouvido aquele nome peculiar pela primeira vez, estamos diante desse processo de revelação histórica às avessas. É o nome lido meses depois (mas, paradoxalmente, dado a ver ao leitor antes) que confere sentido ao obscuro acontecimento passado. Sentido embasado na realidade ou construído a partir da consciência paranóica de um narrador que precisa, a qualquer custo, ver a verdade que teima em lhe escapar?

Apenas o morto poderia responder. A desilusão do narrador com sua busca surge em primeiro plano no parágrafo final do livro, quando este lembrará uma lenda dos índios Nazca peruanos, que "cortavam as línguas dos mortos e as amarravam num saquinho para que nunca mais atormentassem os vivos".

Consciente do dilema insolúvel no qual sua obsessão o enredara, ele abdica da busca pela voz do morto, preferindo talvez não ter nunca lhe dado ouvidos. Aparentemente, essa impossibilidade de dar sentido ao passado, ou para sermos um pouco menos catastróficos, essa dificuldade de estabelecer certezas - a única é a morte - é um dos pontos em que repousa a força pungente de Nove noites. 